\title{
Improving The Students' Self-Confidence in Speaking English Through Youtube
}

\author{
Tri Pujiani $^{1^{*}}$, Khoirun Nisa ${ }^{2}$, Benny Krisbiantoro ${ }^{3}$ \\ University Harapan Bangsa, Street Raden Patah 100 Ledug Kembaran, Purwokerto 53182, Indonesia \\ ${ }^{1}$ tripujiani@uhb.ac.id*; ${ }^{2}$ khoirunnisa@uhb.ac.id; ${ }^{3}$ bennykrisbiantoro@uhb.ac.id \\ * corresponding author \\ Submission date: 15 Februari 2021, Receipt date: 14 Maret 2021, Publication date: 1 April 2021
}

\begin{abstract}
Speaking in English is often a frightening specter for students since they feel unconfident with their English skills. This research was aimed to improve the students' self-confidence in Speaking English by utilizing YouTube as the media. This research was a quasi-experiment involving 43 students chosen randomly. The result of this research showed that there was an increase on the students' self-confidence and speaking performance after they joined this project. Moreover, paired t-test proved that the increase was significant. Thus, it can be concluded that YouTube is effective to increase the students' self-confidence as well as their speaking performance.
\end{abstract}

Keywords: self-confidence, speaking skill, YouTube, English Language Teaching

\section{INTRODUCTION}

Language is one of the means of communication. The most important thing for the success of communication is the way people convey their meaning or ideas (Aamer Qureshi, 2013). The form of communication that is most used in daily life is conversation. Thus, speaking skill is considered as the main skill of communication (Aamer Qureshi, 2013; Srinivas Rao, 2019). Generally, speaking is an activity of pronouncing words, communicating verbally, conveying ideas and doing transaction (James, Yong, \& Yunus, 2019; Leong \& Ahmadi, 2017). Nurlaila and Paramitha adds that speaking is a part of daily life (Paramitha, 2016). However, speaking is the most difficult skill to be mastered (Srinivas Rao, 2019) because it is more spontaneous, chaotic, disorganized, informal, concise and clear rather than written language which is structured and coherent (Khalil, El-nagar, \& Awad, 2019). Moreover, speaking is a complex activity involving all the linguistic elements such as pronunciation, grammar, vocabulary, fluency, and comprehension (Leong \& Ahmadi, 2017). It means that a meaningful utterance should be right in the structure, diction, pronunciation, intonation, and context (James et al., 2019). The mistake in these linguistic elements may cause misunderstanding in communication.

There are many factors influencing people's speaking skill, including linguistic factors and non-linguistic factors. Self-confidence is the main non-linguistic factor that influences someone's speaking skill. On the other side, it is also the problem most commonly faced by people in speaking foreign language (Heriansyah, 2012; Tuan \& Mai, 2015). Self-confidence is one of the elements of self-perception that leads to a 
feeling or strong believe toward self-ability or skill in solving the problems and achieving goals (Bunaya \& Basikin, 2019; Daeli \& Kurnianingtias, n.d.). Selfconfidence is not an absolute thing, it may be changed depending on the situation and can be trained (Daeli \& Kurnianingtias, n.d.). To improve someone's self-confidence, it must be started from the individual itself by being honest to himself, giving selfappreciation, thinking positively, being brave to take the risk and being grateful (Paramitha, 2016). Especially for increasing self-confidence in speaking, it can be trained by being relax, preparing well, practicing more, having peer review, and having teacher to train (Bunaya \& Basikin, 2019).

Talking from the teacher's point of view, it is necessary to give the students enough space to have more practice and get adequate feedback. However, the limited time for speaking activity in the classroom often makes it is impossible for the teacher to give each student a chance to speak and give them feedback one by one. Therefore, the students should not only rely on the teacher and have practice by themselves outside the class. The problem is how to motivate the students to have self-practice out of the class. Considering that self-confidence is the most important thing to be improved in solving the obstacle in speaking English (Oktavia (2016), n.d.) and self-practice is needed to train it, utilizing something interesting and close to them is one of the way.

Some research prove that implementing an interested teaching method such as role play, think pair share, and self-directed dialogue, may increase the students' selfconfidence (Bunaya \& Basikin, 2019; Kurniawati, 2013; Mareta, 2019). Moreover, in this digital era of technology and information social media is one of the alternatives for this problem. Mulyani states that Indonesian social media users are the second biggest in the world that is dominated by 18-24 years old users (Mulyani, 2019). Her research about Facebook proves that the use of social media may solve the problem of limited time in the classroom and it can facilitate the students to practice their language skill out of the class. The other research shows that expanding the speaking activity in social media can give positive impact toward the students' speaking performance and selfconfidence at once (Su \& Fatmawati, 2019). Regarding this previous research, the use of social media seems promising to increase the students' self-confidence as the barrier in speaking English. However, none of them highlight the use of YouTube as the channel to post the students' work. Posting the students' work on YouTube is not merely about accomplishing the course assignments but also to actualize their self as social human being.

In this digital era of industry 4.0, the role of social media is very crucial, especially for self-actualisation, socialization and also business (Mulyani, 2019). YouTube is one of the most popular ones. It is the third most visited website, after google and Facebook (Moghavvemi, Sulaiman, Jaafar, \& Kasem, 2018). Since 2005, YouTube has been the most popular free video sharing website for content creators (Lee \& Lehto, 2013). It is a website in which the users may search many videos without log in and they can also develop their own channel by signing up and creating an account (Jaffar, 2012). Thus, students can easily find a lot of educational contents to improve their English skill. Moreover, YouTube can also be a media to post the students' speaking performance since they can make their own channel and then upload their video on it. By making a video, the students have chance to prepare well and do some editing before finally it is uploaded in their YouTube channel. This enables them to 
make sure that their speaking performance in the video is good and gradually increase their self-confidence.

Considering the hypothesis above, a research on the use of YouTube to increase the students' self-confidence in Speaking English is highly necessary. Thus, this research was aimed to know whether the students' activity in making video and uploading it in YouTube may increase their self-confidence in Speaking English. Furthermore, the result of this research may improve the teachers' knowledge about the suitable teaching method for education 4.0 and can also be used as reference for other researchers who are conducting related research.

\section{RESEARCH METHODS}

This research used quasi experimental one-group pre and post-test design. This method is defined as a quasi-experimental research in which there is one group observed with dependent variable from its group being measured before and after the treatment(Quasi-Experimental and Single-Case Experimental Design, 2019). There were three variables in this research, two dependent variables and one independent variable. The dependent variable measured in this research was students' selfconfidence and the students' speaking performance. Meanwhile, as the independent variable, YouTube was utilized as the media to improve the students' self-confidence in speaking English. The steps of this research were begun by socialization of the project to the students. Then, the students who were interested to join this research were asked to sign the informed consent provided by the researchers as the evidence that the students agreed to be the subject of the research. Next, the students were asked to fill the first self-confidence questionnaire to know the overview of their level of confidence in speaking English. The next step was preparation. The researchers prepared the syllabus and materials covered in this project. After that, the assignments were distributed, and the students began to make the videos based on the topic given. Later, those videos were uploaded in youtube through their own youtube channel. Then, the researchers checked the video one by one and gave score on their speaking performance. After the students had finished the assignment, they were asked to fill the self-confidence questionnaire again. This questionnaire was used to know the students' self-confidence after doing the project. The last steps were data analysis, evaluation and drawing conclusion.

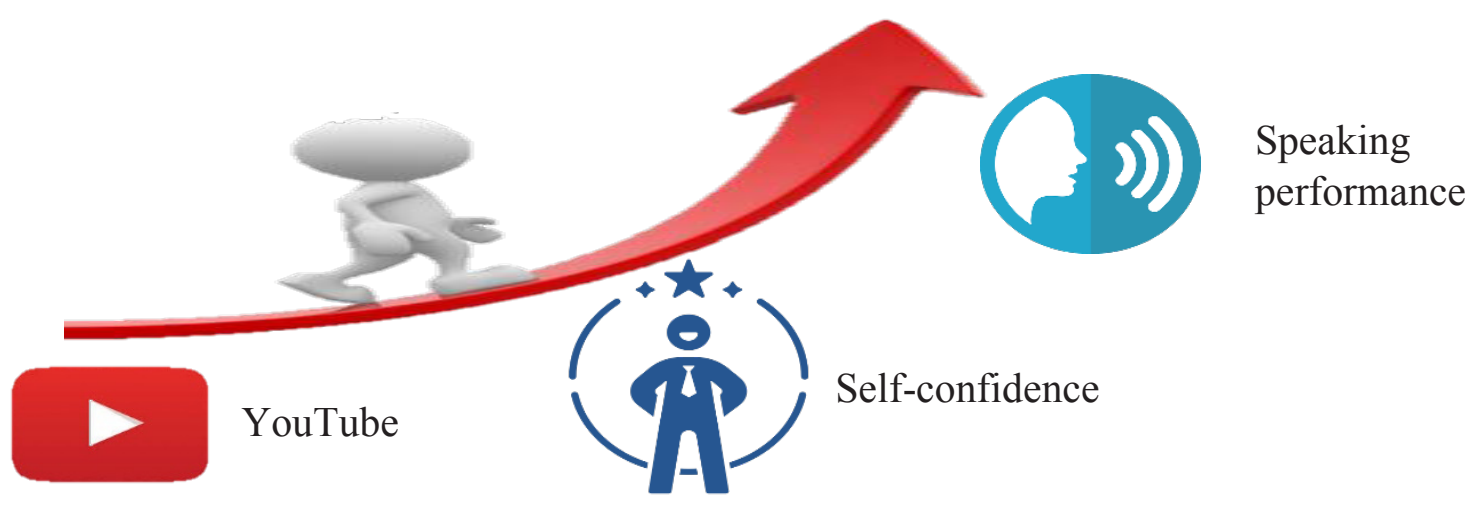

Figure 1. Conceptual Research Framework 


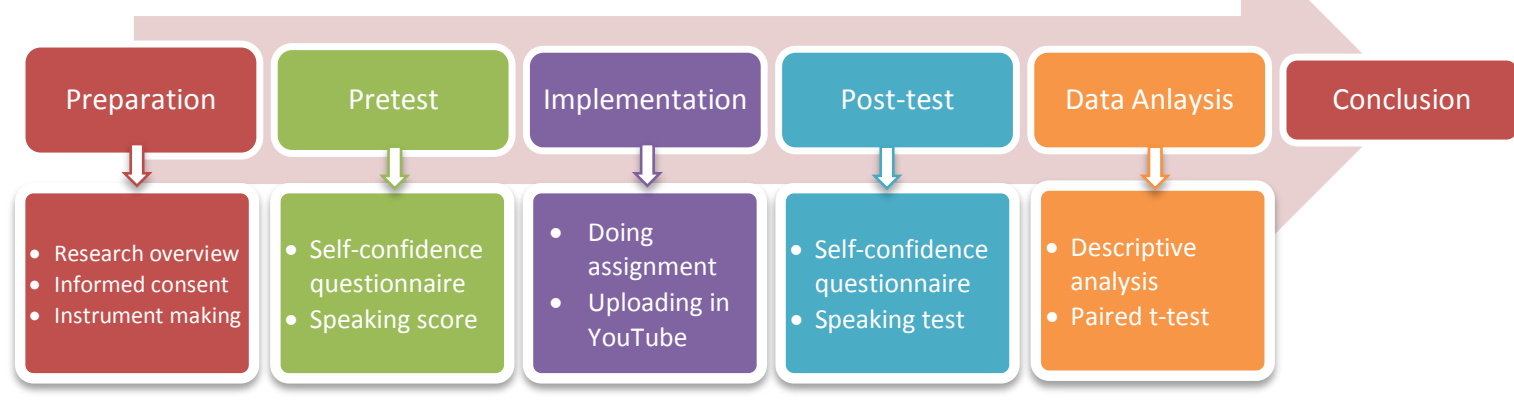

Figure 2. Conceptual Research Flowchart

This research was conducted during the even semester of academic year 2019/2020 that was on March-June 2020. Due to the pandemic of covid-19, the students did the assignment at their home, and online chat was used for coordination and consultation. The population of this research was the students of Harapan Bangsa University, and then it was specified to the second-year students of Undergraduate of Nursing as the sample. There were two classes involved in this research, they were class $4 \mathrm{~A}$ and $4 \mathrm{~B}$ as many as 43 students. They were chosen randomly by using random sampling.

The instruments used in this research were speaking test and questionnaire. The students' speaking performance was tested related to English for Nursing topic. Meanwhile, the questionnaire used was adapted from the questionnaire previously used by the other researchers. They were Bunaya and Basikin who were also adopted the questionnaire from Coopersmith's book entitled "The Antecedents of Self-Esteem". This questionnaire was valid because it has been used by the previous researchers (Bunaya \& Basikin, 2019). The data used in this research were taken from observation, interview, questionnaire, and test. The data from observation and interview were described on discussion. Meanwhile, the data from questionnaire and test were analysed by using descriptive statistics and paired t-test. The descriptive statistics included mean, mode, media, and standard deviation. Paired t-test was used to know if the difference between before and after the treatment given to the same group was significant or not.

\section{RESULTS AND DISCUSSION}

In this section, it will be explained the implementation process of the research, the finding of the research, and the discussion of the finding obtained.

\section{A. Research Implementation}

This research was conducted on May-June 2020 in Harapan Bangsa University. Due to the pandemic of covid-19, this project became the part of e-learning implementation given in English for Nursing Course. As the alternative of speaking assessment which cannot be done directly, the students were assigned to make videos showing their speaking performance related to the topic learnt during the semester and 
then uploaded them in YouTube. Although all students participated in this project, only the data from those signed the informed consent were used in this research.

To know the difference of students' speaking performance before and after the project, the students' verbal evaluation score last semester and current semester were compared. Those scores were taken using the same scoring components described on the scoring rubric by excluding the aspect of comprehension. This was because the materials learnt last semester was different from the ones given in the current semester so that their comprehension must be different. Therefore, the components assessed were purely the speaking performance.

Meanwhile, to know the improvement of the students' self-confidence, the researcher compared the result of questionnaire given before and after the project. The questionnaire was used Likert scale. So, the data was quantitative and analysed by using descriptive statistics and paired t-test.

\section{B. Finding}

The findings of this research consisted of two data. The first was the students' speaking score and the second was the students' self-confidence level. The following table shows the students' verbal scores on the previous semester, semester 3, in which their speaking skill was assessed directly.

Table 1. The Summary of Students' Verbal Scores on Semester 3

\begin{tabular}{ccccccc}
\hline $\mathrm{N}$ & Mean & Mode & Median & $\begin{array}{c}\text { Standard } \\
\text { Deviation }\end{array}$ & Highest & Lowest \\
\hline 43 & 81 & 80 & 81 & 5,0 & 91 & 70 \\
\hline
\end{tabular}

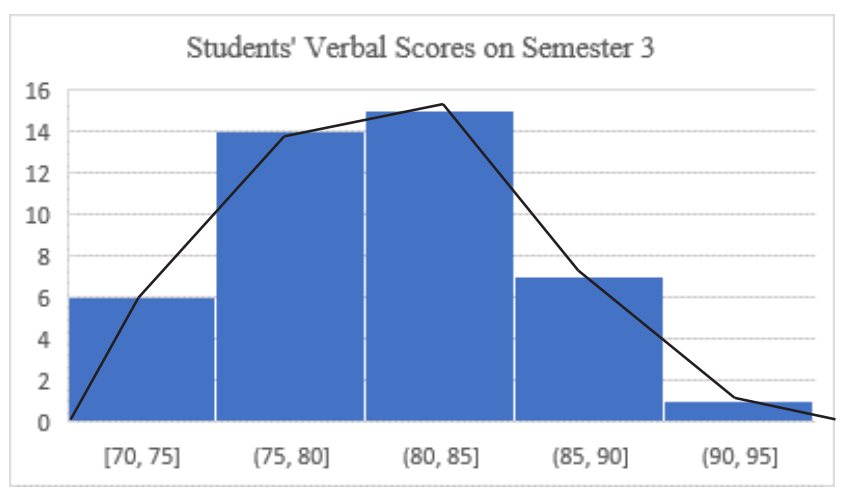

Figure 3. Histogram and Polygon of Students' Verbal Scores on Semester 3

Last semester, the students' average score was 81 . The highest score was 91 and the lowest score was 70 . The most appeared score was 80 . The middle score was 81 and the standard deviation was 5,0. Figure 3 shows the frequency distribution of these scores.

Meanwhile, on the current semester, due to the pandemic of covid-19, all the learning activities were transformed to be online. Thus, the students speaking skill was assessed by making videos and uploading them in YouTube. Their scores were described on the following table. 


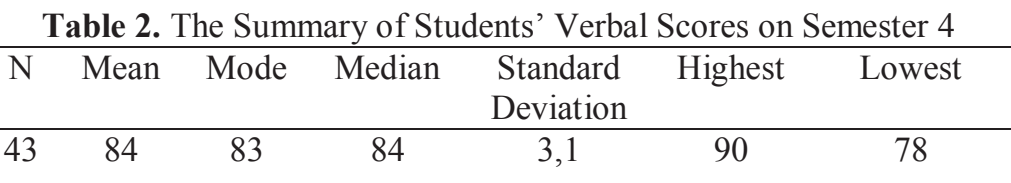

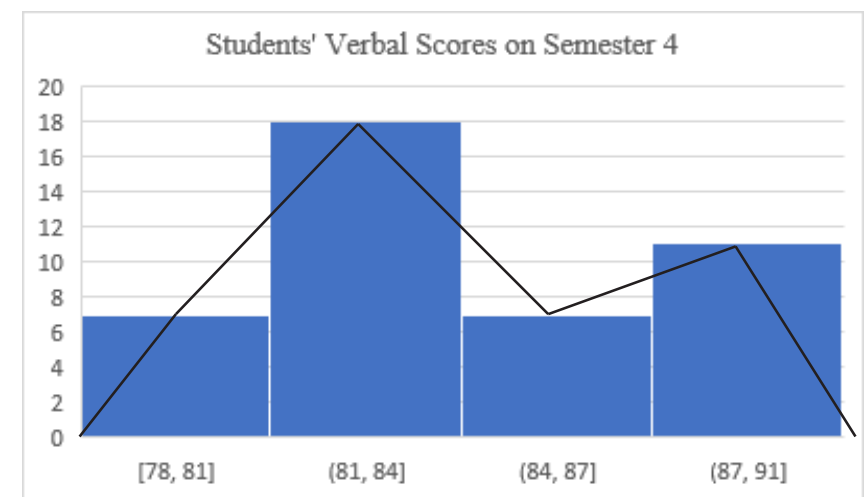

Figure 4. Histogram and Polygon of Students' Verbal Scores on Semester 4

Based on table 2, there was an increase on the mean score. It was 84 . The most appeared score was 83 and the middle score was 84 . The standard deviation was 3,1 with the highest score was 90 and the lowest score was 78. Figure 4 shows the frequency distribution of these scores. Although there was an increase on the students' verbal scores this semester, it is needed to know whether the increase was significant or not. That is why paired-t test was applied to compare those two scores. Following is the summary of paired t-test.

Table 3. The Result of Paired T-Test of Verbal Score

\begin{tabular}{ccccccc}
\hline N & df & $\begin{array}{c}\text { t- } \\
\text { table }\end{array}$ & stdev & t-cal & Desc. & analysis \\
\hline 43 & 42 & 1,68 & 5,2 & 3,77 & significant & $\begin{array}{c}\mathrm{H}_{0} \text { was } \\
\text { rejected }\end{array}$ \\
\hline
\end{tabular}

Referring to table 3 , t-calculated $(3,77)$ was higher that t-table $(1,68)$. It means that the increase on the students' verbal scores was significant. So, the null hypothesis was rejected.

The students' self-confidence was assessed before and after joining this project by using self-confidence questionnaire. Following is the summary of the first selfconfidence questionnaire that shows the students' self-confidence level on Speaking English directly.

Table 4. The Summary of Self-confidence Pretest

\begin{tabular}{ccccccc}
\hline N & Mean & Mode & Median & $\begin{array}{c}\text { Standard } \\
\text { Deviation }\end{array}$ & Highest & Lowest \\
\hline 43 & 34,5 & 28 & 34 & 4,7 & 45 & 27 \\
\hline
\end{tabular}




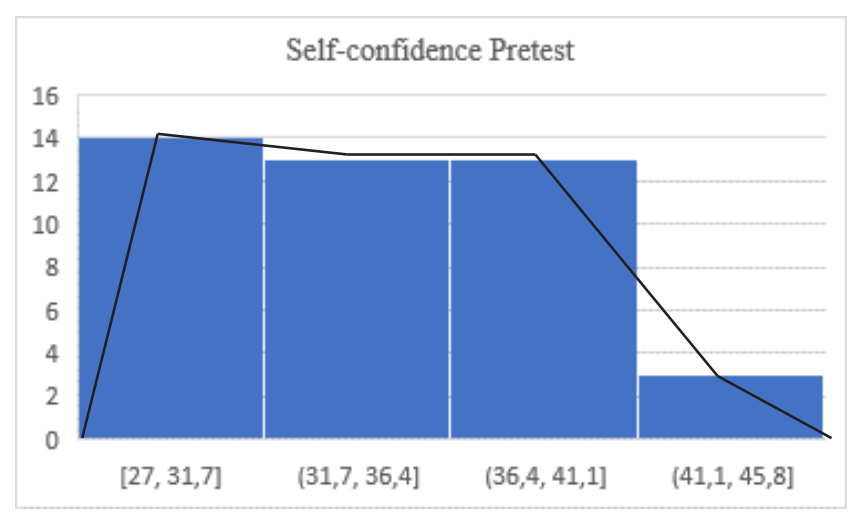

Figure 5. Histogram and Polygon of Self-Confidence Pretest

Based on table 4, the mean score of students' self-confidences was 34,5 out of 60 . The most appeared score was 28 . The middle score or median was 34 . The highest score was 45 and the lowest score was 27 . From this data, it was obtained that the standard deviation was 4,7. Figure 5 shows the frequency distribution of these scores.

This pre-test score was compared with post-test score which was obtained from self-confidence questionnaire distributed after the students joined the project. Following table shows the summary of the post-test scores.

Table 5. The Summary of Self-confidence Posttest

\begin{tabular}{ccccccc}
\hline $\mathrm{N}$ & Mean & Mode & Median & $\begin{array}{c}\text { Standard } \\
\text { Deviation }\end{array}$ & Highest & Lowest \\
\hline 43 & 48,2 & 52 & 50 & 5,1 & 53 & 24
\end{tabular}

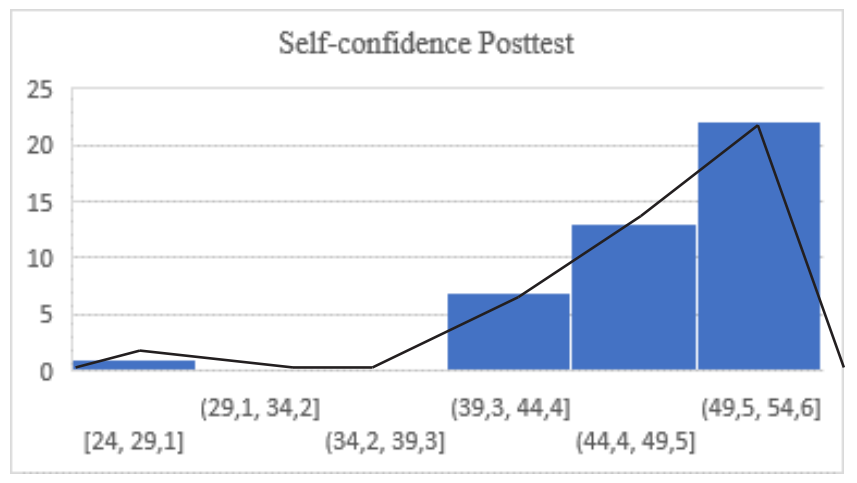

Figure 6. Histogram and Polygon of Self-Confidence Posttest

Different from the pre-test score, the students' self-confidence on the post-test was higher. The mean score was 48,2. The most appeared score was 52 . The middle score was 50 and the standard deviation was 5,1 . The range of these scores was wider with the highest was 53 and the lowest was 24. Figure 6 shows the frequency distribution of the post-test scores.

Based on both questionnaire results, the students' self-confidence was higher when they spoke through video rather than spoke directly in front of the lecturer. To know whether the difference was significant or not, paired t-test was applied. Following table shows the result of paired t-test. 
Table 6. The Result of Paired T-Test of Students' Self-Confidence

\begin{tabular}{lllllll}
\hline $\mathbf{N}$ & df & t-table & stdev & t-cal & Desc. & analysis \\
\hline 43 & 42 & 1,68 & 7,2 & 12,45 & significant & $\begin{array}{l}\mathrm{H}_{0} \text { was } \\
\text { rejected }\end{array}$ \\
\hline
\end{tabular}

From the table above, t-calculated is higher than t-table. It means that the difference was significant, and the null hypothesis was rejected. So, it could be interpreted that the use of YouTube as the media of expressing English speaking performance was effective to increase the students' self-confidence.

\section{Discussion}

According to the data obtained, it was known that there was increase on both, students' speaking performance and self-confidence, after this project was implemented. It meant that the hypothesis of this research was accepted. The use of YouTube as the media to post the students' assignment affected the students' self-confidence in a positive way. Then, the students' self-confidence influenced their speaking performance. Those with high self-confidence could perform better than those with low self-confidence. Based on the result of informal interview and questionnaire analysis, it was known that the students' main problem in speaking English was that they felt less confidence. Furthermore, they felt hesitate to speak English outside the class because they felt shy and afraid of making mistakes. However, after joining this project they stated that sharing ideas in YouTube was fun and they could lower their nervousness because they could prepare everything before they spoke. In addition, knowing that their performance would be shared for public encouraged them to do the best in finishing their assignment before uploading it in YouTube.

YouTube is one of the most popular social media that is currently growing up widely. Because it is something that is close to the students, YouTube becomes an interesting media to be utilized to encourage the students to improve their learning motivation. By posting the students' assignment in YouTube, it gave some benefit for the students speaking performance. First, knowing that their posts would be watched and evaluated by public increase the students' awareness that they must perform or do the assignment well. Thus, they followed some procedures including planning, recording, evaluating, re-recording, and posting. Second, these procedures promoted practice. The more the students evaluated their work, the more they knew about their weaknesses. The more they took the recording, the more practice they had. Third, it helped the students to overcome their limitations in speaking. This project enabled the students to have more preparation time before they submitted the assignment. During the process of making the video, they had chance to minimize some mistakes in their speaking. They might edit the video and check their overall performance before posting it. Therefore, they would be more confidence about their performance (Su \& Fatmawati, 2019).

In addition, without self-confidence the students will not be able to perform their speaking well since self-confidence is the main factor influencing the speaking performance (Su \& Fatmawati, 2019). Thus, this project was designed to decrease the students' anxiety, afraid, and shyness in speaking English. It was expected that this 
could eventually shape the student's self-confidence and increase their English-speaking skill.

Speaking is not an easy skill to be mastered. It is a complex activity involving all language elements (Leong \& Ahmadi, 2017). Mastering Speaking Skill almost equals to mastering English in general. Due to it is complex activity, the problem faced by the students may be different. However, whatever the problems found in speaking English, it will be easier to be done if they have good self-confidence (Oktavia (2016), n.d.). Therefore, stimulating the students' self-confidence is important if we want to improve their speaking skill. In this project, the students used feedback from the lecturer and comments from their friends to evaluate their performance. It was reasonable that there were still some mistakes on their first post. And then, they would revise it on the next post. That was why their performance became gradually better and better.

\section{CONCLUSION}

Based on the result of the discussion, it can be concluded that improving the students' self-confidence is important to increase the students' speaking skill. The use of YouTube has proven effective in increasing students' self-confidence as well as their speaking performance. However, this project needs to be continued and developed because when it stops the students will back to their problem, no more speaking practice, and lack of self-confidence. Thus, it was recommended that there will be the other project that utilize YouTube as the media to learn or practice English.

\section{REFERENCES}

Aamer Qureshi, I. (2013). The Importance Of Speaking Skill For Efl Learners. Gerald Gillis. Https://Doi.Org/10.1093/Bioinformatics/Btt640

Bunaya, M. S., \& Basikin. (2019). Improving Speaking Confidence By Using Think Pair Share (Tps) Teaching Strategy To High School Students. Https://Doi.Org/10.2991/Iccie-18.2019.59

Daeli, R., \& Kurnianingtias, E. A. (N.D.). Measuring Self-Confidence Of Teenage Students Of Sekolah Cita Buana.

Heriansyah, H. (2012). Speaking Problems Faced By The English Department Students Of Syiah Kuala University. Lingua Didaktika: Jurnal Bahasa Dan Pembelajaran Bahasa. Https://Doi.Org/10.24036/Ld.V6i1.7398

Jaffar, A. A. (2012). Youtube: An Emerging Tool In Anatomy Education. Anatomical Sciences Education. Https://Doi.Org/10.1002/Ase.1268

James, P. R. A. P., Yong, K. L., \& Yunus, M. M. (2019). Hear Me Out! Digital Storytelling To Enhance Speaking Skills. International Journal Of Academic Research In Business And Social Sciences. Https://Doi.Org/10.6007/Ijarbss/V9$\mathrm{I} 2 / 5533$

Khalil, A. H., El-Nagar, B. E. E., \& Awad, M. A. E. (2019). The Effect Of Brain-Based Learning On Developing Some Speaking Skills Of Egyptian Efl Secondary School 
Students. 14(3), 103-116.

Kurniawati, A. (2013). Using Role-Play Technique For The Eight Grade. I-152.

Lee, D. Y., \& Lehto, M. R. (2013). User Acceptance Of Youtube For Procedural Learning: An Extension Of The Technology Acceptance Model. Computers And Education. Https://Doi.Org/10.1016/J.Compedu.2012.10.001

Leong, L.-M., \& Ahmadi, S. M. (2017). An Analysis Of Factors Influencing Learners' English Speaking Skill. International Journal Of Research In English Education. Https://Doi.Org/10.18869/Acadpub.Ijree.2.1.34

Mareta, Silviani (University Of L. (2019). Improving The Self-Confidence In Speaking Practice By Using Self-Directed Dialogue Technique At Second Grade Students' Of Smp Negeri 1 Kalirejo Lampung Tengah. 300.

Moghavvemi, S., Sulaiman, A., Jaafar, N. I., \& Kasem, N. (2018). Social Media As A Complementary Learning Tool For Teaching And Learning: The Case Of Youtube. International Journal Of Management Education. Https://Doi.Org/10.1016/J.Ijme.2017.12.001

Mulyani, H. (2019). Penggunaan Media Sosial Sebagai Penunjang Dalam Pekuliahan Anggaran Perusahaan Di Program Studi Pendidikan Akuntansi. Jurnal Pendidikan Akuntansi \& Keuangan. Https://Doi.Org/10.17509/Jpak.V3i2.15437

Oktavia (2016), N. A. (N.D.). Enhancing Students' Self Confidence To Overcome Speaking Problem By Nidya Andini Oktavia. 1-10.

Paramitha, G. T. (2016). Tingkat Percaya Diri Peserta Didik. Kesehatan. Https://Doi.Org/10.1017/Cbo9781107415324.004

Quasi-Experimental And Single-Case Experimental Design. (2019). Sage Publication.

Srinivas Rao, P. (2019). The Importance Of Speaking Skills In English Classrooms. Alford Council Of International English \& Literature Journal(Acielj).

Su, Y. R., \& Fatmawati, F. (2019). Fostering Students' Self-Esteem In Speaking By Extending Speaking Activities In Social Media. Pedagogy: Journal Of English Language Teaching, 7(1), 65. Https://Doi.Org/10.32332/Pedagogy.V7i1.1544

Tuan, N. H., \& Mai, T. N. (2015). Factors Affecting Students' Speaking Performance At Le Thanh Hien High School. Asian Journal Of Educaitonal Research. 